ESJ Social Sciences

\title{
Long-run Effects of Market Risk Factors on Bank Performance in the SSA Banking System
}

\author{
Changjun Zheng \\ School of Management, \\ Huazhong University of Science and Technology, Wuhan, China \\ Sinamenye Jean-Petit \\ School of Management, \\ Huazhong University of Science and Technology, Wuhan, China \\ Burundi National School of Administration
}

Doi:10.19044/esj.2021.v17n41p130

Submitted: 29 October 2021

Accepted: 29 December 2021

Published: 31 December 2021
Copyright 2021 Author(s)

Under Creative Commons BY-NC-ND

4.0 OPEN ACCESS

Cite As:

Zheng C. \& Jean-Petit S. (2021). Long-run Effects of Market Risk Factors on Bank Performance in the SSA Banking System. European Scientific Journal, ESJ, 17 (41), 130. https://doi.org/10.19044/esj.2021.v17n41p130

\begin{abstract}
The study assesses the long-term effects of market risk factors on bank performance in the Sub-Saharan Africa banking system. The article identifies the most influential market risk factor and the most affected bank performance factors in the long term. It covers 40 countries with 350 commercial banks for ten years. The analysis uses dynamic fixed-effects models (ARDL-DFE). The results demonstrated that non-performing loans are the most influencers affecting bank performance factors in the long run. Furthermore, the results show that return on average assets is the most bank performance factor affected mainly by market risks, especially the NPLs in the long run. Finally, the findings surprisingly proved mutual interactions and cointegration movements among bank market risk factors and bank performance measures in the long run. These findings can assist central banks in supervising and regulating SSA commercial banks and inspire regional bank managers in reducing market risks and sharpening long-run performance strategies through resource reallocating.
\end{abstract}

Keywords: Bank, Performance, Risk, Loans, Africa 


\section{Introduction}

"Caring bank market risks is caring for bank performance."

Every business involves risks. However, bank operations are engaged in a high degree of risk-taking behavior due to lending activities. Bank operations require certain wisdom and accuracy with a certain degree of intelligent analysis as those operations deal with significant investments. Mostly, those substantial investments may not necessarily come from bank ownership. Then, the leveraged investment and the credit volume offered to the customers determine the crucial part of bank risks. These two activities make the intermediation institutions in riskier firms operating in high business risk mainly when analysed from the default rate side (Eichengreen et al., 2012).

The bank risk-taking behavior has been studied using different types of bank risks measures/metrics: market risks factors (credit growth risks, loan loss provision/reserves risks, and non-performing loans risks), operational risks (Belkhir et al., 2019). From another point of view, bank risks can be classified as systematic and unsystematic (Simpson, 2007). Other authors used business risks, country risks, or legal and environmental bank risks to categorise the bank risks (Greuning \& Bratanovic, 2009; Weber, 2012). Thus, for top managers and investors, understanding the dangers of engaging in business and deciding on credit volume and investment portfolio is critical for bankers, investors, and the whole society. Moreover, mastering long-run market risk factors and their effects on bank performance is also crucial for business and risk management.

The market risks represent a part of bank risk factors. Those market risk factors can be analysed from a different point of view based on the authors' research objectives. Some researchers identified their macroeconomic and bank-specific determinants of market risks separately: non-performing loans by (Fofack \& Fofack, 2005; Khemraj \& Pasha, 2009; Mpofu \& Nikolaidou, 2018; Saba et al., 2012; Škarica, 2014); loan loss reserves by (Isa et al., 2018; Saurina, 2009; ul Mustafa et al., 2012; Z. Wang et al., 2019); and credit growth by (Tan, 2012; Vithessonthi, 2016).

However, this study will not assess their determinant. Instead, it will use all these three variables together in the same model as risk measures to evaluate their long-run effect on bank performance. Therefore, the bank market risks will be assessed as a whole of bank systemic risks. Performance factors will be proxied by two return variables (ROAA, ROAE) and one intermediation cost (NIM). Then, on the one hand, the bank performance will be systematically assessed separately in each model (as dependent variables) to evaluate their different changes and check how they are differently affected by market risk factors. 
On the other hand, the study will compare the performance coefficients, determine the most influential among all bank market risk factors, and identify the most affected among the three bank performance factors. A new comparison will be made to ensure which bank performance factor is highly affected by market risk factors in the long run. And finally, this paper intends to prove that the bank performance factors have a mutual effect for the long run. As far as we know, these long-run effects and most influential market risk factors, mutual influences of bank performance, and comparison of the most affected among factors in the banking system may not have been studied previously.

Hereafter, our five research questions were formulated: do the bank market risk measures affect all the bank performance proxies in the long run? Which is the most influential among bank market risk metrics in the long run? Which bank performance factor is mostly affected by market risk in the long run? Is there any long-run mutual effect among bank performance factors? And finally, can we confirm that caring bank market risk is caring bank performance in the long run?

Two hypotheses have been developed from the above questions: three general and three specific. The first general hypothesis is stated as follows "The market risk measures affect bank performance differently." From this, we deduct two particular approaches: the first one is that "the NPLs are the most influential among bank risk-taking metrics, in the long run." The second hypothesis is that "the returns on assets are the most affected by NPLs among bank performance proxies, in the long run as well."

The second general hypothesis is stated as follows: "in the long run, there are mutual influences among bank performance proxies." The specific theory formulated from that second general hypothesis is that: "The effect of returns on average assets is considered to be higher than the effect of return on average equity, in the long run." Then the third general and concluding hypothesis is formulated as follows: "caring bank market risk factor is caring bank performance, in the long run."

This paper is therefore organised as follows: After this introductory part, the following part is about the literature review on bank risk performance. The third part is concerned with the methodology (econometric models and statistical tests used), data source, and variables description. The fourth and last part discusses the results and the findings before the concluding portion.

\section{Literature review}

Since the '90s, several banks have experienced business downturns, and different financial institutions have experienced losses due to various crises (Murphy, 2008). These crises have negatively affected the total bank credit volume and reduced the bank performance consequently (Fassin \& 
Gosselin, 2011; Lane \& Milesi-Ferretti, 2011; Önder \& Özyıldırım, 2013): In Europe, for instance, Fortis as the principal Benelux business group (Fassin \& Gosselin, 2011; Nguyen \& Qian, 2014); recently in 2008, in the US particularly, the lemon brother bank (Ivashina \& Scharfstein, 2010; Johnson \& Mamun, 2012).

But one study found that liquidity, capital adequacy, and profitability were negatively associated with credit risk but insignificant statistically (Tehulu \& Olana, 2014). Other studies have analysed loan growth's effect on bank profitability: credit growth is positively associated with bank profitability (Dang, 2019), while Fahlenbranch investigates why fast loans predict poor bank performance (Fahlenbrach et al., 2018). In this point of view, the author converges with some authors who worked on bank risk and proved how credit growth increases bank risks(Amador et al., 2013; Foos et al., 2010). A study done in Vietnam showed how lending increases loan loss reserves and decreases the capital ratio the following year, while banks' profit is positively associated with loan growth for the long and short term (Dang, 2019). For Jijun Niu, rapid loan growth is correlated to higher valuations in moderate banks but not in big banks (Niu, 2016).

Jolevski found a negative correlation between return on equity, return on assets, and non-performing loans. The author concludes that the real sector's profitability affects the fluctuations of non-performing loans considerably (Jolevski, 2017). While analysing NPL determinants, Rachman concludes that bank profitability and net interest margin (NIM) are included among those determinants (Rachman et al., 2018). These findings converge with some other authors who worked on NPLs determinants. (Ghosh, 2015; Klein \& Weill, 2018).

A relationship between credit growth, non-performing loans, and bank profitability was found in the Japan Banking system. The same study demonstrated a significant positive association between non-performing loans and credit growth. However, he added that they have no impact on bank profit. He concluded that the rise in bank credits intensifies NPLs and does not lead to considerable gain (Vithessonthi, 2016). Conversely, our findings find a substantial effect between NPLs and ROAA in the long run. A study on the association between the loan loss provision (LLP) and bank performance showed a positive impact of LLRs on bank profitability(ul Mustafa et al., 2012). One more study found that NPLs were negatively and significantly correlated to the ROAA and the net loans to deposit ratio (Dicevska et al., 2018). In Bangladesh commercial banks, one study proved that NIM is highly determined by the credit risk factors, especially loan loss reserve and nonperforming loans (Rahman et al., 2015).

In Nigeria, determinants of bank profitability showed that nonperforming loans affect negatively and significantly the bank performance 
(Owoputi et al., 2014). However, in Ghana, another study demonstrated that bank performance is positively associated with credit risk proxied by loan loss (Gyamerah \& Amoah, 2015). In Kenya, loan loss provision was found to be statistically significant to the profitability of Kenya commercial banks (Sawe, 2011).

\section{Methodology, variables, and data source.}

\subsection{Data source and variables}

\subsection{1. variable descriptions}

In the initial model, we used both regional and bank-specific variables. The Macroeconomic variables are TGE, INLAT, and DGPGR. The INLAT represents inflation as a consumer price index, and DGPGR denotes the gross domestic product growth. Then, the TGE represents the total government expenses and the CPSB, the bank's credit to the private sector. All these four variables have been downloaded from the world bank database. Other remaining bank-specific variables were taken from bank Focus, Bureau Van Dijk, and are as follows: NIM represents the net interest margin. At the same time, ROAA and ROAE characterise the average assets and equity return. The LLR is the loan loss reserves/provisions, and the NPLs represent the nonperforming loans. These variables used the ratios already calculated and available in the bank Focus database.

\subsubsection{Data source and sample size.}

Table1: Study scope and share of the sample size.

Figure 1: sample size by region

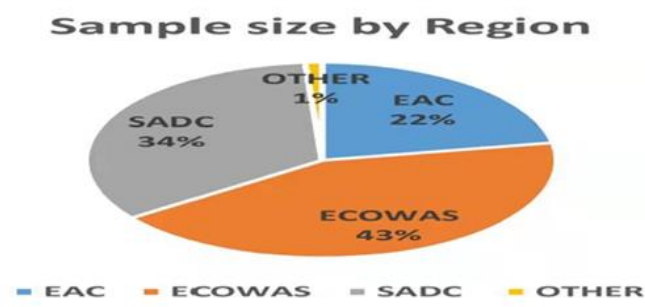

Table1: Study scope and the sample size.

\begin{tabular}{|c|c|c|c|c|}
\hline Regions & State members & $\begin{array}{c}\text { State } \\
\text { S }\end{array}$ & Obs. & $\%$ \\
\hline EAC & $\begin{array}{c}\text { Burundi, Kenya, Tanzania, Rwanda, } \\
\text { Uganda and South Soudan }\end{array}$ & 6 & 770 & 22.13 \\
\hline ECOWAS & $\begin{array}{c}\text { Be'nin, le Burkina Faso, le Cap Vert,la } \\
\text { Co^ te d'Ivoire, la Gambie, le Ghana, la } \\
\text { Guine'e, la Guine'e Bissau, le Libe'ria, le } \\
\text { Mali, le Niger, le Nige'ria, la Sierra } \\
\text { Leone, le Se'ne'gal et le Tgo, }\end{array}$ & 15 & 1,490 & 42.82 \\
\hline
\end{tabular}




\begin{tabular}{|c|c|c|c|c|c|}
\hline \multirow[t]{3}{*}{$\begin{array}{l}\mathbf{S} \\
\mathbf{S} \\
\mathbf{A}\end{array}$} & SADC & $\begin{array}{c}\text { Angola, Botswana, Comoros, Democratic } \\
\text { Republic of Congo, Eswatini, Lesotho, } \\
\text { Madagascar-car, Malawi, Mauritius, } \\
\text { Mozambique, Namibia, Sey-Chelles, } \\
\text { South Africa, Tanzania, Zambia, and } \\
\text { Zimbabwe }\end{array}$ & 16 & 1,180 & 33.91 \\
\hline & Other & Ethiopia and Djibouti & 3 & 40 & 1.15 \\
\hline & & Total & 40 & 3,480 & 100 \\
\hline
\end{tabular}

Table2 is a short panel data (larger $\mathrm{N}$ and small $\mathrm{T}$ ) covering ten years from 2010 to 2019, and this panel is a cross-sectional and times series combination. In this study, 40 countries are concerned as sample size, with 350 banks operating in the SSA region. The study covers ten years and uses 3480 observations from 350 banks. The region encompasses three central communities: EAC (East African Community), SADC (South African development community), and ECOWAS (economic community of West African countries). The ECOWAS region is the first with 15 states (43\% of the coverage sample). The SADC is second with 16 states (34\% of the total sample size). The EAC comes in the third position with six countries (22\% of the sample size). The other countries represent $1.15 \%$, with three states. The calculated ratios were downloaded from the two abovementioned sources that we organised, cured, and uploaded for model and test analysis in the Stata system. The logarithm form of data was used to avoid the inflated standard error.

\subsubsection{Descriptive statistics.}

Table 2 for Descriptive statistics.

\begin{tabular}{|c|c|c|c|c|c|}
\hline Variables & Obs & Mean & Std. Dev. & Min & Max \\
\hline ROAE & 1952 & 2.286 & 1.492 & -3.353 & 8.449 \\
\hline NPL & 1340 & 2.113 & 1.335 & -5.739 & 8.332 \\
\hline LLR & 1441 & 1.568 & 1.328 & -7.844 & 7.612 \\
\hline FD & 3051 & 2.9 & .748 & 1.308 & 10.602 \\
\hline ED & 1902 & 2.082 & 3.024 & -.919 & 19.012 \\
\hline TGE & 3480 & 2.991 & .064 & 2.81 & 3.036 \\
\hline
\end{tabular}

Source: Author computation

Table1 summarises the variables used in this study. It shows the number of observations, the mean, the standard deviation, minimum and maximum. The three first bank-specific variables have almost the same standard deviation $(1.492,1.335$, and 1.328), and even their mean does not vary too much. However, the ED has the highest standard deviation (3.024) while TGE has the lowest. This difference can be explained because the total 
government expenses do not vary too much with the time in SSA countries. However, the highest standard deviation for ED is explained because the GDP growth among countries varies with the time among SSA countries.

\subsection{Methodology}

\subsubsection{Preliminary tests: correlation and unit-roots test.}

The preliminary correlation test among variables is conducted with the Pearson correlation matrix (Pearson, 1901). This matrix evidences the linear relationship between in the used model. The second test is unit-roots. The test is essential to check for non-stationary. There are many tests for panel data (Im et al., 2003; Levin et al., 2002; M. H. Pesaran et al., 1999). For simplicity, we performed only the IPS test (which assumes that the slopes are heterogeneous) and the ADF-Fisher test, which work well with the unbalanced panel data. Fisher-type unit-root test also includes AR parameter, panel means, and time trends. This test generates four statistics (P, Z, T, and PM) (Harris \& Tzavalis, 1999).

\subsubsection{General ARDL model}

The ARDL model, called the autoregressive distributed lag model, is an OLS (ordinary least square). This model is appropriate for the time-series dataset and has different advantages. The model is broadly recognised for the cointegration analysis in the time series dataset. As in our case study, the ARDL model is mainly efficient for a small sample size. Another key benefit of this ARDL modelling method is that it does not care whether the regressors are (0) or I (1). Once again, ARDL allows a considerable number of lags. Moreover, it will expand a dynamic error correction model that organises short and long-run effects with unbiased estimates, as it considers all long-run data. The generalised form of the ARDL (p, q) model is specified as follow:

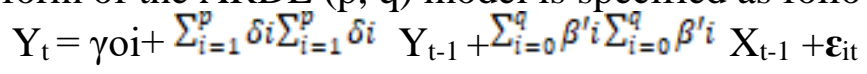

\subsubsection{ARDL-PMG, $M G$, and DFE models}

The ARDL method uses different techniques (pooled mean group (PMG), mean group (MG), or dynamic fixed effect (DFE). These techniques are appropriate based on the aim of this research and are suitable for a small panel data set $(\mathrm{T}<\mathrm{N})$ with 40 cross-sections and ten times series.

ARDL-PMG estimators are flexible whether variables exhibit I $(0)$, I(1), or a mixture of both (Pesaran and Shin 1998) and can take care of such heterogeneity with PMG-DFE techniques. Additionally, this method has the power to capture the interesting variable dynamics in both the long and shortrun (H. H. Pesaran \& Shin, 1998).

The pooled mean group method uses the averaged and pooled coefficients of cross-sectional units. It allows the long-run effects' restriction 
to be the same across all the panels. However, it permits the short-run effects across panels to be country-specific (heterogonous) as caused by differences in country-specific policies.

Contrary to the MG method allowing heterogeneity in both long and short-run relationships, the DFE (Dynamic Two-Way Fixed Effect) technique allows homogenous in the short-run and is selected based on a comparison of the best estimations results of Hausman tests between PMG, MG, and DFE (M. H. Pesaran et al., 1999; M. H. Pesaran \& Smith, 1995). Furthermore, the slope, speed of adjustment, and short-run coefficient are restricted with DFE methods to exhibit homogeneity across countries.

Theen, the ARDL-DFE error correction model is re-parameterized as follow;

$$
\begin{aligned}
& \Delta \mathrm{Yit}=\theta_{i}\left[\mathrm{Y}_{i, t-1}-\Lambda_{\mathrm{i}} \mathrm{X}_{i, t}\right]+\sum_{j=1}^{p-1} \xi_{i j} \sum_{j=1}^{p-1} \xi_{i j} \Delta \mathrm{Y}_{i, t-j}+\sum_{j=0}^{q-1} \beta^{\prime} \Sigma_{j=0}^{q-1} \beta^{\prime}{ }_{i j} \Delta \mathrm{X}_{i, t-j}+\varphi_{i}+ \\
& \varepsilon_{i t}
\end{aligned}
$$

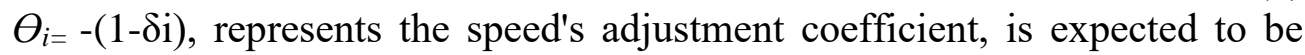
negative. $K_{\mathrm{i}}$ is a long-run relationship vector. ECT $=\left[\mathrm{Y}_{i, t-1}-\Lambda_{\mathrm{i}} \mathrm{X}_{i, t}\right]$; is representing the error correction term. $\xi^{i j} \xi^{i j}$ and $\beta^{y} \beta^{r} \mathrm{ij}$ represent the short run dynamic coefficients. From equations (2), then we can obtain DFE models specified as follows:

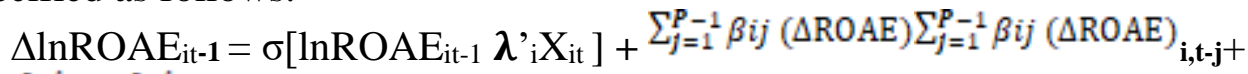

$$
\begin{aligned}
& \sum_{j=0}^{q-1} \delta j \sum_{j=0}^{q-1} \delta j(\Delta \ln X)_{t-j}+\varphi \varphi_{i}+\varepsilon_{i t}
\end{aligned}
$$$$
\Delta \operatorname{lnROAA} A_{\mathrm{it}-1}=\sigma\left[\operatorname{lnROAA} A_{\mathrm{it}-1} \lambda^{\prime}{ }_{\mathrm{i}} \mathrm{X}_{\mathrm{it}}\right]+{ }_{j=1}^{P-1} \beta i j(\Delta \mathrm{ROAA}) \sum_{j=1}^{P-1} \beta i j(\Delta \mathrm{ROAA}){ }_{\mathrm{i}, \mathrm{j}+}+
$$$$
\sum_{j=0}^{q-1} \delta j \sum_{j=0}^{q-1} \delta j(\Delta \ln X)_{t-j}+\varphi \varphi_{\mathrm{I}}+\varepsilon_{\mathrm{it}}
$$

$\Delta \operatorname{lnNIM} \mathrm{it}-1=\sigma\left[\operatorname{lnNIM} \mathrm{it}-1^{\prime} \lambda_{\mathrm{i}} \mathrm{X}_{\mathrm{it}}\right]+\sum_{j=1}^{P-1} \beta i j(\Delta \mathrm{NIM}) \sum_{j=1}^{P-1} \beta i j(\Delta \mathrm{NIM})_{\mathrm{i}, \mathrm{t}-\mathrm{j}+} \sum_{j=0}^{q-1} \delta j$ $\sum_{j=0}^{q-1} \delta j(\Delta \ln X)_{t-j}+\varepsilon_{i t}$

\section{Empirical results and discussions}

\subsection{Unit roots and correlation matrix results}

Table 3 for unit roots results

\begin{tabular}{|c|c|c|c|c|}
\hline \multirow{2}{*}{ Tests } & \multicolumn{4}{|c|}{ unit-root tests } \\
\hline $\mathrm{I}(0) / \mathrm{I}(1)$ & \multicolumn{2}{|c|}{ Im-Pesaran-Shin test (IPS) } & \multicolumn{2}{c|}{ ADF-Fisher Test } \\
\hline & At level & $\begin{array}{c}\text { At first } \\
\text { difference }\end{array}$ & At level & $\begin{array}{c}\text { Atfirst } \\
\text { difference }\end{array}$ \\
\hline FD & -26.420 & $-10.357 * * *$ & -7.1436 & $-7.143 * * *$ \\
\hline ED & $1.601 * * *$ & $-38.480 * * *$ & 0.4967 & $0.169 * * *$ \\
\hline ROAE & $-6.220 * *$ & $-1.816 * * *$ & $-15.468 * * *$ & $-19.614 * * *$ \\
\hline NPLs & -1.065 & $3.1463 * * *$ & -5.5628 & $-6.628 * * *$ \\
\hline LLR & $-2.447 * * *$ & $9.0540 * * *$ & $-1.449 * * *$ & $-13.971 * * *$ \\
\hline TGE & -6.063 & $0.55 * * *$ & $-16.453 * * *$ & $-18.654 * * *$ \\
\hline
\end{tabular}




\begin{tabular}{|c|c|c|c|c|}
\hline ROAA & $2.51 * * *$ & $-3.68 * * *$ & $-11.132 * * *$ & $-22.515 * * *$ \\
\hline NIM & -0.29 & $-40.775 * * *$ & $-30.326 * * *$ & $-7.371 * * *$ \\
\hline
\end{tabular}

Table 2 presents the unit-roots results for the variables. At level, four variables are only significant for the IPS test, while at the first difference, all variables are significant. For the ADF-Fisher test, which summarizes all the tests, the variables are significant at the first difference. The overall results imply that the series are all stationary at first difference. Nevertheless, Cointegration analysis was done through the plotted graph 1 and 3. Correlation analysis was also done to check whether there is no linear dependency among the repressors. Details on correlation analysis results can be checked in Tables 1,2 , and 3 of appendix A.

\subsection{Empirical results and discussions}

First of all, all the three speeds of adjustment are negative for all three regressions. The negative sign implies and exhibits the long-run effect among studies variables. Secondly, the results showed that few bank performance variables are affected in the short-run compared to the long-run effects. Similarly, the ROAE is affected by NPLs for the short term, at a 5\% significance level, ceteris paribus. Lastly, among the macroeconomic variables, only GDPGR is the one which can affect NIM and ROAA respectively in the long run at 5\% and $10 \%$ significant level, ceteris paribus. In the short run, the bank risk factors affect only one bank performance variable: ROAA: The ROAA is negatively and significantly affected by $\mathrm{CPSB}$, at a $1 \%$ significant level, ceteris paribus. In the same way, the ROAA is significantly and positively affected by the LLR, at a $1 \%$ significant level, ceteris paribus.

However, the bank risk factors considerably influence the bank performance factors in the long run: the NPLs are the most influential bank risk factors that significantly and positively affect the ROAA ceteris paribus, at a $1 \%$ significant level. Conversely, NPLs impact negatively and significantly the ROAE and NIM ceteris paribus, at a $1 \%$ significant level.

Table 5: Long and Short run ARDL-DFE results

\begin{tabular}{|c|c|c|c|c|c|c|c|}
\hline \multicolumn{2}{|l|}{ Models } & \multicolumn{2}{|c|}{ Model 1: ROAA } & \multicolumn{2}{|c|}{ Model 2 : ROAE } & \multicolumn{2}{|c|}{ Model 3: NIM } \\
\hline Period & Vars & Coeff. & t-stat & Coeff. & t-stat & Coeff. & t-stat \\
\hline & ROAA & - & - & $\begin{array}{l}1.397 * * * \\
(.400)\end{array}$ & 3.49 & $\begin{array}{l}.062 \\
(.125)\end{array}$ & 0.50 \\
\hline & ROAE & $\begin{array}{l}.164 * * * \\
(.039)\end{array}$ & 4.17 & - & - & $\begin{array}{l}.025 \\
(.034)\end{array}$ & 0.74 \\
\hline Long & NIM & $\begin{array}{l}.173 \\
(.274)\end{array}$ & 0.63 & $\begin{array}{l}.233 \\
(.563)\end{array}$ & 0.42 & - & - \\
\hline
\end{tabular}




\begin{tabular}{|c|c|c|c|c|c|c|c|}
\hline \multirow[t]{5}{*}{ Run } & $N P L$ & $\begin{array}{l}1.034 * * * \\
(.049)\end{array}$ & -6.94 & $\begin{array}{l}-.732 * * * \\
(.035)\end{array}$ & -2.69 & $\begin{array}{l}-.139 * * \\
(.005)\end{array}$ & 2.35 \\
\hline & $L L R$ & $\begin{array}{l}-.723 * * * \\
(.152)\end{array}$ & -4.74 & $\begin{array}{l}-.633^{* *} \\
(.347)\end{array}$ & -1.82 & $\begin{array}{l}.034 \\
(.107)\end{array}$ & 0.37 \\
\hline & $C P S B$ & $\begin{array}{l}-.227 * * * \\
(.075)\end{array}$ & -3.02 & $\begin{array}{l}.275 * * * \\
(.162)\end{array}$ & 1.69 & $\begin{array}{l}.087 * * \\
(.046)\end{array}$ & 1.89 \\
\hline & GDP & $\begin{array}{l}.039 * \\
(.004)\end{array}$ & 8.18 & $\begin{array}{l}-.517 \\
(.849)\end{array}$ & -0.61 & $\begin{array}{l}-.481 * * \\
(.260)\end{array}$ & -1.85 \\
\hline & TGE & $\begin{array}{l}-.074 \\
(.182)\end{array}$ & -0.41 & $\begin{array}{l}.496 \\
(.326)\end{array}$ & 1.52 & $\begin{array}{l}-.158 \\
(.098)\end{array}$ & -1.60 \\
\hline \multirow{9}{*}{$\begin{array}{l}\text { Short } \\
\text { - } \\
\text { Run }\end{array}$} & ECT & $\begin{array}{l}-.843 * * * \\
(.063)\end{array}$ & -13.38 & $\begin{array}{l}-1.01 * * * \\
(.052)\end{array}$ & -19.35 & $\begin{array}{l}-.931 * * * \\
(.122)\end{array}$ & -7.61 \\
\hline & ROAA & - & - & $\begin{array}{l}.135 \\
(.246)\end{array}$ & 0.55 & $\begin{array}{l}-.022 \\
(.067)\end{array}$ & -0.34 \\
\hline & ROAE & $\begin{array}{l}.003 \\
(.008)\end{array}$ & 0.41 & - & - & $\begin{array}{l}-.008 \\
(.014)\end{array}$ & -0.63 \\
\hline & NIM & $\begin{array}{l}-.131 \\
(.168)\end{array}$ & -0.78 & $\begin{array}{l}-.038 \\
(.450)\end{array}$ & 0.09 & - & - \\
\hline & NPL & $\begin{array}{l}-.296 * * * \\
(.048)\end{array}$ & -6.11 & $\begin{array}{l}.143 * * \\
(.151)\end{array}$ & 0.95 & $\begin{array}{l}.007 \\
(.041)\end{array}$ & 0.19 \\
\hline & LLR & $\begin{array}{l}.296 * * * \\
(.052)\end{array}$ & 5.64 & $\begin{array}{l}.323 \\
(.246)\end{array}$ & 1.31 & $\begin{array}{l}.047 \\
(.067)\end{array}$ & 0.70 \\
\hline & CPSB & $\begin{array}{l}.070 \\
(.045)\end{array}$ & 1.56 & $\begin{array}{l}-.227 \\
(.121)\end{array}$ & -1.88 & $\begin{array}{l}.018 \\
(.033)\end{array}$ & 0.54 \\
\hline & GDP & $\begin{array}{l}.039 \\
(.004)\end{array}$ & 8.18 & $\begin{array}{l}.140 \\
(.650)\end{array}$ & 0.22 & $\begin{array}{l}.185 \\
(.175)\end{array}$ & 1.05 \\
\hline & TGE & $\begin{array}{l}.086 \\
(.118)\end{array}$ & 0.34 & $\begin{array}{l}-.305 \\
(.244)\end{array}$ & -1.25 & $\begin{array}{l}.042 \\
(.066)\end{array}$ & 0.63 \\
\hline
\end{tabular}

***,**, and $*$ indicate statistical significance at the 1\%, 5\%, and $10 \%$ levels respectively. The standard errors are in between paratheses.

The LLR is the second influential bank risk factor in the long run: LLR impacts negatively and significantly the ROAE and ROAA ceteris paribus, at a $1 \%$ significant level. Moreover, the LLR effect on ROAA and ROAE is significant at short- and long-run levels. NPLs also affect negatively and significantly NIM, at a $1 \%$ significant level, ceteris paribus. The third and last bank risk factor affecting bank performance is the CPSB. The ROAA is affected negatively and significantly at $1 \%$ significant level, ceteris paribus by CPSB, while ROAE is influenced positively and significantly at $1 \%$ significant level, ceteris paribus by CPSB. NIM is impacted significantly and positively at a $5 \%$ significant level, ceteris paribus by CPSB. 
Finally, there is a long-run mutual effect among bank performance factors: for the long-run, ROAA impacts positively and significantly (1.397) ROAE at a $1 \%$ significant level, ceteris paribus. Conversely, in the long run, ROAE influences positively and significantly (.164) ROAA at a $1 \%$ significant level, ceteris paribus.

\section{The ARDL_DFE long-run results summary}

This table summarises only the long-run results. Three models with three bank performance factors as dependent variables were developed. Each model includes the three market risks measures (see from model3 to model5). Each bank performance factor plays the role of becoming an independent variable of other bank performance variables.

Tabe 6: Long-run coefficients comparison.

\begin{tabular}{|c|c|c|c|c|c|c|}
\hline Models & \multicolumn{2}{|c|}{ Model 1: ROAA } & \multicolumn{2}{c|}{ Model 2: ROAE } & \multicolumn{2}{c|}{ Model 3: NIM } \\
\hline Variables & Coefficient & t-stat & Coefficient & t-stat & Coefficient & t-stat \\
\hline NPL & $1.034 * * *$ & -6.94 & $\begin{array}{c}-.732^{* * *} \\
(.109)\end{array}$ & -2.69 & $-.139 * *$ & -1.75 \\
& & $(.272)$ & & $(.081)$ & \\
\hline LLR & $-.723^{* * *}$ & -4.74 & $\begin{array}{l}.633^{* *} \\
(.152)\end{array}$ & -1.82 & .034 & 0.37 \\
& $(.154)$ & & $(.107)$ & \\
\hline CPSB & $-.227 * * *$ & -3.02 & $\begin{array}{c}.275^{* * *} \\
(.162)\end{array}$ & 1.69 & $.087 * *$ & 1.89 \\
& $(.075)$ & & $(.046)$ & \\
\hline
\end{tabular}

Note: $* * *, * *$, and $*$ indicate statistical significance level at the $1 \%, 5 \%$, and $10 \%$ respectively. The standard errors are in between paratheses.

Thus we can deduct some inferences from these results analysis: Firstly, in the long run, the NPLs are the most influencers of bank performance variables than LLR and CPSB. The second conclusion is that ROAA is the most affected by market risk factors and the most significant in the long run. The third deduction from these results is that even though there is a mutual influence in the long run between ROAA and ROAE, the effect of ROAA on ROAE is considerably higher than the effect of ROAE on ROAA. (1.397 against 0.164).

Then, these results confirm our three general and specific hypotheses: all market risks measures/metrics affect different bank performance proxies. That deduction permits us to make the last confirmation assuming that: "caring bank mark risk is caring bank performance. Furthermore, these results analysis and deductions have some additional meaning. If the enormous amount of bank returns are from ROAA, the real state/assets absorb a considerable part of the bank's capital and investments. Conversely, suppose the small amount of banks' returns are generated by equities; in that case, it implies that banks are less engaged in traditional activities, which are the primary function of the commercial banks (Valentseva, 2017). On the banks' 
side, this strategy is safe on the one hand but not beneficial for SSA societies on the other hand, which primarily relies on small businesses as most developing countries (Beck et al., 2008; Du Toit \& Neves, 2007). Many businesses, especially SMEs in developing countries, need more intermediaries institutions to channel the funds from those who have surplus to those in need, as documented by Enterprise survey data and publications from the World Bank (Nizaeva \& Coşkun, 2018; Y. Wang, 2016).

Playing safer while relying much more on ROAA returns than ROAE returns is not a bad strategy. However, the banking system may experience a decrease in liquidity that can affect the whole banking system. Then that effect can be viral and provoke a regional financial crisis ( see references in the literature review). It is better to have a balanced return system and bank activities/operations equilibrium for a sustainable banking system. That can be done through the central bank's market risk regulation and supervision. Those tools can inspire commercial banks' decision-making on credit volume reallocation.

\subsection{Effect analysis through graphs.}

4.2.1. Positive Cointegration movements in Bank risk and bank Performance Factors in SSA banking system (figure1)

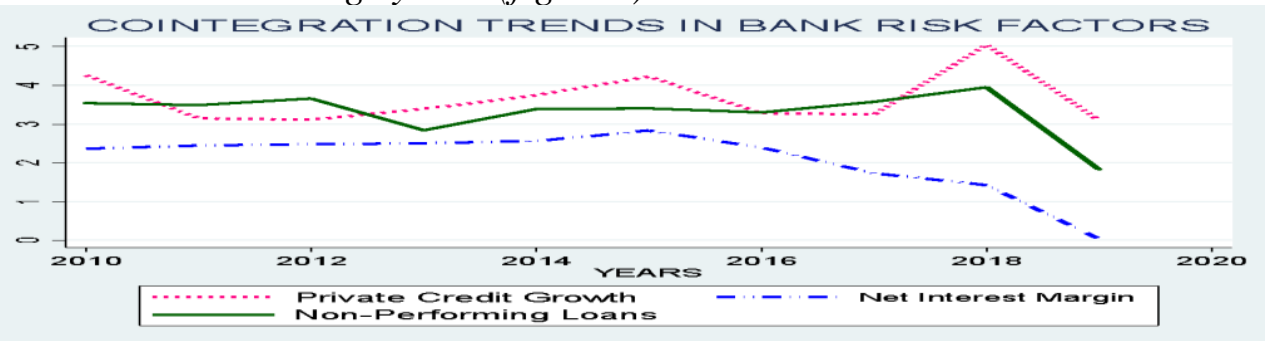

Figurel illustrates the negative cointegration among the bank market risk metrics. From 2010, we observe that CPSB is trending downwards up to 2011 and take and stability up to 2012. In that same period, NPLs are trying to raise a little bit. From 2012, both bank market metrics take the opposite direction: CPSB rises to 2015 while NPLs decline for one year. Then it takes stability for one year, up to 2016. From 2016, they both start with opposite directions up to 2018, where they both take a decline in the same direction. However, NIM followed their rising trends quickly, from 2010 to 2015. Then took a decrease from that period up to 2017, where it considerable decline up to 2019. This figure converges with the Dynamic Fixed Effect regression results' long-run results (see tble5). 
4.2.2. Inverse correlation (NPLs \& ROAE, figure2) and Cointegration movements (LLR \& ROAE, figure3) and bank Performance Factors
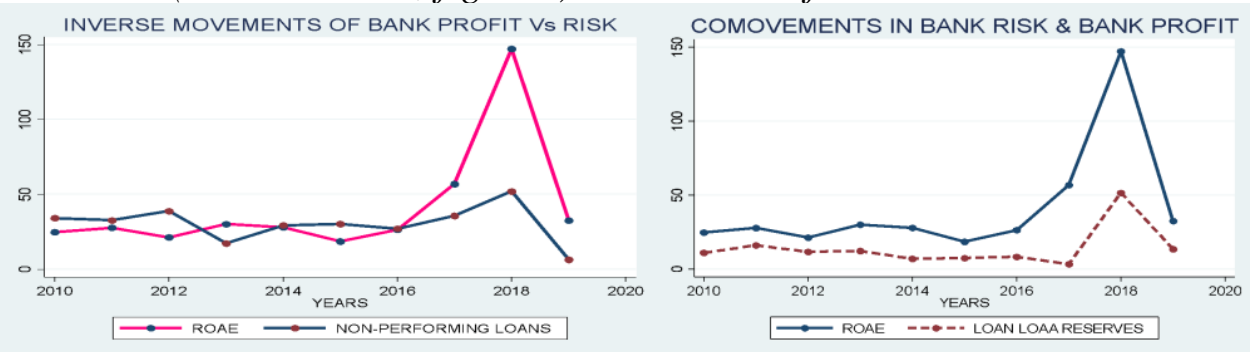

Figure 3 represents a perfect and positive cointegration between ROAE and LLR. From 2010 up to 2019, the two variables exhibit perfect positive correlation movements. This figure corroborates the long-run regression results presented in the regression results (see table5). Furthermore, it justifies the bounds results obtained in the table4. Nevertheless, from figure5, we observe some weak negative trends between NIM and LLR. From 2010 to 2016, NIM trends rise while LLR trends are declining. From there, LLR takes a sharp and quick rise and declines while NIM keeps falling from 2015 up to 2019. These two variables exhibit opposite correlations.

4.3. Model robustness and post estimation.

\begin{tabular}{|c|c|c|c|c|}
\hline Tests & Ho & Ha & Chi2 & $\begin{array}{l}\text { Results and } \\
\text { Decision }\end{array}$ \\
\hline \multicolumn{5}{|c|}{ Model 1 ROAE } \\
\hline Durbin-Watson & $\begin{array}{l}\text { No serial } \\
\text { correlation }\end{array}$ & Serial correlation & $\begin{array}{l}\text { d-statistic } \\
(15,3479)\end{array}$ & $\begin{array}{l}\text { 1.999202: } \\
\text { Can not reject Ho }\end{array}$ \\
\hline $\begin{array}{l}\text { Breusch- } \\
\text { Godfrey } \\
\text { LM test }\end{array}$ & $\begin{array}{l}\text { No serial } \\
\text { correlation }\end{array}$ & Serial correlation & 0.001 & $\begin{array}{l}0.9812 \\
\text { Can not reject Ho }\end{array}$ \\
\hline White's test & $\begin{array}{l}\text { Homoskedasti } \\
\text { city }\end{array}$ & $\begin{array}{l}\text { unrestricted } \\
\text { heteroskedasticit } \\
\mathrm{y}\end{array}$ & 3479.00 & $\begin{array}{l}0.0000 \\
\text { Can not reject Ho }\end{array}$ \\
\hline \multirow{4}{*}{$\begin{array}{l}\text { Cameron \& } \\
\text { Trivedi's } \\
\text { decomposition } \\
\text { of IM-test }\end{array}$} & $\begin{array}{l}\text { Homoskedasti } \\
\text { city }\end{array}$ & $\begin{array}{l}\text { Heteroskedasticit } \\
\mathrm{y}\end{array}$ & 3479.00 & $\begin{array}{l}0.0000 \\
\text { Can not reject Ho }\end{array}$ \\
\hline & \multirow{3}{*}{$\begin{array}{l}\text { Additional } \\
\text { tests }\end{array}$} & Skewness & 827.52 & 0.0000 \\
\hline & & Kurtosis & 1.69 & 0.1933 \\
\hline & & Total & 4308.21 & 0.0000 \\
\hline \multicolumn{5}{|c|}{ Model 2 ROAA } \\
\hline Durbin-Watson & $\begin{array}{l}\text { No serial } \\
\text { correlation }\end{array}$ & Serial correlation & $\begin{array}{l}\text { d-statistic } \\
(16,3479)\end{array}$ & $\begin{array}{l}2.00375: \\
\text { Can not reject Ho }\end{array}$ \\
\hline $\begin{array}{l}\text { Breusch- } \\
\text { Godfrey } \\
\text { LM test }\end{array}$ & $\begin{array}{l}\text { No serial } \\
\text { correlation }\end{array}$ & Serial correlation & 0.012 & $\begin{array}{l}0.9118 \\
\text { Cannot reject Ho }\end{array}$ \\
\hline
\end{tabular}




\begin{tabular}{|c|c|c|c|c|}
\hline White's test & $\begin{array}{l}\text { Homoskedasti } \\
\text { city }\end{array}$ & $\begin{array}{l}\text { unrestricted } \\
\text { heteroskedasticit } \\
\mathrm{y}\end{array}$ & 3479.00 & $\begin{array}{l}0.0000 \\
\text { Can not reject Ho }\end{array}$ \\
\hline \multirow{4}{*}{$\begin{array}{l}\text { Cameron \& } \\
\text { Trivedi's } \\
\text { decomposition } \\
\text { of IM-test }\end{array}$} & $\begin{array}{l}\text { Homoskedasti } \\
\text { city }\end{array}$ & $\begin{array}{l}\text { Heteroskedasticit } \\
\mathrm{y}\end{array}$ & 3479.00 & $\begin{array}{l}0.0000 \\
\text { Can not reject Ho }\end{array}$ \\
\hline & \multirow{3}{*}{$\begin{array}{l}\text { Additional } \\
\text { tests }\end{array}$} & Skewness & 522.39 & 0.0000 \\
\hline & & Kurtosis & 3.23 & 0.0723 \\
\hline & & Total & 4004.62 & 0.0000 \\
\hline \multicolumn{5}{|c|}{ Model 3 NIM } \\
\hline Durbin-Watson & $\begin{array}{l}\text { No serial } \\
\text { correlation }\end{array}$ & Serial correlation & 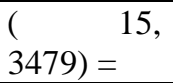 & $\begin{array}{l}2.001914 \\
\text { Can not reject Ho }\end{array}$ \\
\hline $\begin{array}{l}\text { Breusch- } \\
\text { Godfrey } \\
\text { LM test } \\
\end{array}$ & $\begin{array}{l}\text { No serial } \\
\text { correlation }\end{array}$ & Serial correlation & 0.003 & $\begin{array}{l}0.9549 \\
\text { Can not reject Ho }\end{array}$ \\
\hline White's test & $\begin{array}{l}\text { Homoskedasti } \\
\text { city }\end{array}$ & $\begin{array}{l}\text { unrestricted } \\
\text { heteroskedasticit } \\
\mathrm{y}\end{array}$ & 3479.00 & $\begin{array}{l}0.0000 \\
\text { Can not reject Ho }\end{array}$ \\
\hline \multirow{4}{*}{$\begin{array}{l}\text { Cameron \& } \\
\text { Trivedi's } \\
\text { decomposition } \\
\text { of IM-test }\end{array}$} & $\begin{array}{l}\text { Homoskedasti } \\
\text { city }\end{array}$ & heteroskedastic & 3479.00 & $\begin{array}{l}0.0000 \\
\text { Can not reject Ho }\end{array}$ \\
\hline & \multirow{3}{*}{$\begin{array}{l}\text { Additional } \\
\text { tests }\end{array}$} & Skewness & 647.02 & 0.0000 \\
\hline & & Kurtosis & 1.42 & 0.2328 \\
\hline & & Total & 4127.45 & 0.0000 \\
\hline
\end{tabular}

This table summarises the results of the Homoskedasticity and serial correlation tests for the three models developed in this study. The following tests were tested; Durbin-Watson's null hypothesis states no serial correlation against the alternative of serial correlation. Breusch-Godfrey LM test: the null hypothesis states no serial correlation against the alternative. White's Heteroskedasticity test and Cameron \& Trivedi's decomposition of IM-test for Skewness and Kurtosis were also tested. The results showed no serial correlation in the three models, and the models are homoscedastic. These results corroborate the correlation matrix of no correlation among independent variables (see table1, 2 and 3 in appendix A).

\section{Conclusion}

The main objective was to determine the most influential market risk factor on the one hand and the most affected among bank performance proxies in the long run on the one hand.

Based on these results obtained from ARDL-DFE and discussion on results, this study confirmed hypotheses. It made three conclusions: first, market risk factors affect bank risk differently. Secondly, non-performing loans are the most influential market risk. Finally, the return on average asset is the most affected bank performance factor. 
These results and conclusions are corroborated and supported by findings of non-performing loans on bank performance conducted with individual approach (Chimkono et al., 2016; Etale et al., 2016).

\section{Policy implications:}

This study offers a clear view of how the central banks from different countries can advise, supervise, and regulate banks and financial institutions by controlling market risk factors and then mitigating bankruptcy and financial crisis in the region.

Furthermore, the study can help top-level managers of local, regional, and merged banks to mitigate market risks through long-run performance strategies by adjusting and relocating their investments based on the findings presented in this study.

Further research may check the possible relationship between bank performance proxies and other categories of bank risk metrics. For instance, more analysis can check whether long-run effects exist between operational bank risk factors and bank performance proxies or systematic and unsystematic market risks metrics.

\section{References:}

1. Amador, J. S., Gómez-González, J. E., \& Pabón, A. M. (2013). Loan growth and bank risk: new evidence. Financial Markets and Portfolio Management, 27(4), 365-379.

2. Beck, T., Demirgüç-Kunt, A., \& Martinez Peria, M. S. (2008). Bank financing for SMEs around the world: Drivers, obstacles, business models, and lending practices. World Bank Policy Research Working Paper, 4785.

3. Belkhir, M., Grira, J., Hassan, M. K., \& Soumaré, I. (2019). Islamic banks and political risk: International evidence. The Quarterly Review of Economics and Finance, 74, 39-55.

4. Bismark, O.-T. (2021). Non-Performing Loans and Bank's Profitability: Empirical Evidence from Ghana. Ritsumeikan Asia Pacific University.

5. Chimkono, E. E., Muturi, W., \& Njeru, A. (2016). Effect of nonperforming loans and other factors on performance of commercial banks in Malawi. International Journal of Economics, Commerce and Management, 4(2), 549-563.

6. Dang, V. (2019). The effects of loan growth on bank performance: Evidence from Vietnam. Management Science Letters, 9(6), 899-910.

7. Dicevska, S., Karadjova, V., \& Jolevski, L. (2018). The impact of nonperforming loans on households on the financial performance of banks in macedonial. 
8. Du Toit, A., \& Neves, D. (2007). In search of South Africa's second economy: Chronic poverty, economic marginalisation and adverse incorporation in Mt. Frere and Khayelitsha. Frere and Khayelitsha (November 2007). Chronic Poverty Research Centre Working Paper, 102.

9. Eichengreen, B., Mody, A., Nedeljkovic, M., \& Sarno, L. (2012). How the subprime crisis went global: Evidence from bank credit default swap spreads. Journal of International Money and Finance, 31(5), 1299-1318.

10. Etale, L. M., Ayunku, P. E., \& Etale, E. (2016). The impact of nonperforming loans and bank performance in Nigeria. International Journal of Humanities and Social Science Invention, 5(4), 1-5.

11. Fahlenbrach, R., Prilmeier, R., \& Stulz, R. M. (2018). Why does fast loan growth predict poor performance for banks? The Review of Financial Studies, 31(3), 1014-1063.

12. Fassin, Y., \& Gosselin, D. (2011). The collapse of a European bank in the financial crisis: An analysis from stakeholder and ethical perspectives. Journal of Business Ethics, 102(2), 169-191.

13. Fofack, H., \& Fofack, H. L. (2005). Non-performing loans in SubSaharan Africa: causal analysis and macroeconomic implications (Vol. 3769). World Bank Publications.

14. Foos, D., Norden, L., \& Weber, M. (2010). Loan growth and riskiness of banks. Journal of Banking \& Finance, 34(12), 2929-2940.

15. Ghosh, A. (2015). Banking-industry specific and regional economic determinants of non-performing loans: Evidence from US states. Journal of Financial Stability, 20, 93-104.

16. Greuning, H. van, \& Bratanovic, S. B. (2009). Analysing banking risk.

17. Gyamerah, I. A., \& Amoah, B. (2015). Determinants of bank profitability in Ghana. International Journal of Accounting and Financial Reporting, 5(1), 173-187.

18. Harris, R. D. F., \& Tzavalis, E. (1999). Inference for unit roots in dynamic panels where the time dimension is fixed. Journal of Econometrics, 91(2), 201-226.

19. Im, K. S., Pesaran, M. H., \& Shin, Y. (2003). Testing for unit roots in heterogeneous panels. Journal of Econometrics, 115(1), 53-74.

20. Isa, M. Y. M., Choong, Y. V., Fie, D. Y. G., \& Rashid, M. Z. H. A. (2018). Determinants of loan loss provisions of commercial banks in Malaysia. Journal of Financial Reporting and Accounting.

21. Ivashina, V., \& Scharfstein, D. (2010). Bank lending during the financial crisis of 2008. Journal of Financial Economics, 97(3), 319338.

22. Johnson, M. A., \& Mamun, A. (2012). The failure of Lehman Brothers 
and its impact on other financial institutions. Applied Financial Economics, 22(5), 375-385.

23. Jolevski, L. (2017). Non-Performing Loans and Profitability Indicators: The Case of the Republic of Macednia. Journal Of Contemporary Economic And Business Issues, 4(2), 5-20.

24. Khemraj, T., \& Pasha, S. (2009). The determinants of non-performing loans: an econometric case study of Guyana.

25. Klein, P.-O., \& Weill, L. (2018). Bank profitability and economic growth.

26. Lane, P. R., \& Milesi-Ferretti, G. M. (2011). The cross-country incidence of the global crisis. IMF Economic Review, 59(1), 77-110.

27. Levin, A., Lin, C.-F., \& Chu, C.-S. J. (2002). Unit root tests in panel data: asymptotic and finite-sample properties. Journal of Econometrics, 108(1), 1-24.

28. Mpofu, T. R., \& Nikolaidou, E. (2018). Determinants of credit risk in the banking system in Sub-Saharan Africa. Review of Development Finance, 8(2), 141-153.

29. Murphy, A. (2008). An analysis of the financial crisis of 2008: causes and solutions. An Analysis of the Financial Crisis Of.

30. Nguyen, H., \& Qian, R. (2014). Demand collapse or credit crunch to firms? Evidence from the World Bank's financial crisis survey in Eastern Europe. Journal of International Money and Finance, 47, 125144.

31. Niu, J. (2016). Loan growth and bank valuations. The Quarterly Review of Economics and Finance, 61, 185-191.

32. Nizaeva, M., \& Coşkun, A. (2018). Determinants of the financing obstacles faced by SMEs: An empirical study of emerging economies. Journal of Economic and Social Studies, 7(2), 81.

33. Önder, Z., \& Özyıldırım, S. (2013). Role of bank credit on local growth: Do politics and crisis matter? Journal of Financial Stability, 9(1), 13-25.

34. Owoputi, J. A., Olawale, F. K., \& Adeyefa, F. A. (2014). Bank specific, industry specific and macroeconomic determinants of bank profitability in Nigeria. European Scientific Journal, 10(25).

35. Pearson, K. (1901). LIII. On lines and planes of closest fit to systems of points in space. The London, Edinburgh, and Dublin Philosophical Magazine and Journal of Science, 2(11), 559-572.

36. Pesaran, H. H., \& Shin, Y. (1998). Generalised impulse response analysis in linear multivariate models. Economics Letters, 58(1), 17 29.

37. Pesaran, M. H., Shin, Y., \& Smith, R. P. (1999). Pooled mean group estimation of dynamic heterogeneous panels. Journal of the American 
Statistical Association, 94(446), 621-634.

38. Pesaran, M. H., \& Smith, R. (1995). Estimating long-run relationships from dynamic heterogeneous panels. Journal of Econometrics, 68(1), 79-113.

39. Rachman, R. A., Kadarusman, Y. B., Anggriono, K., \& Setiadi, R. (2018). Bank-specific factors affecting non-performing loans in developing countries: Case study of Indonesia. The Journal of Asian Finance, Economics, and Business, 5(2), 35-42.

40. Rahman, M. M., Hamid, M. K., \& Khan, M. A. M. (2015). Determinants of bank profitability: Empirical evidence from Bangladesh. International Journal of Business and Management, 10(8), 135.

41. Saba, I., Kouser, R., \& Azeem, M. (2012). Determinants of nonperforming loans: Case of US banking sector. The Romanian Economic Journal, 44(6), 125-136.

42. Saurina, J. (2009). Loan loss provisions in Spain. A working macroprudential tool. Revista de Estabilidad Financiera, 17, 11-26.

43. Sawe, S. C. (2011). Determinants of Commercial banks profitability in Kenya. University of Nairobi, Kenya.

44. Simpson, J. (2007). Expert political risk opinions and banking system returns: A revised banking market model.

45. Škarica, B. (2014). Determinants of non-performing loans in Central and Eastern European countries. Financial Theory and Practice, 38(1), $37-59$.

46. Tan, M. T. B. P. (2012). Determinants of credit growth and interest margins in the Philippines and Asia. International Monetary Fund.

47. Tehulu, T. A., \& Olana, D. R. (2014). Bank-specific determinants of credit risk: Empirical evidence from Ethiopian banks. Research Journal of Finance and Accounting, 5(7), 80-85.

48. ul Mustafa, A. R., Ansari, R. H., \& Younis, M. U. (2012). Does the loan loss provision affect the banking profitability in case of Pakistan? Asian Economic and Financial Review, 2(7), 772.

49. Valentseva, N. I. (2017). The scope of traditional activities of commercial banks. Finance: Theory and Practice, 21(2), 51-54.

50. Vithessonthi, C. (2016). Deflation, bank credit growth, and nonperforming loans: Evidence from Japan. International Review of Financial Analysis, 45, 295-305.

51. Wang, Y. (2016). What are the biggest obstacles to growth of SMEs in developing countries?-An empirical evidence from an enterprise survey. Borsa Istanbul Review, 16(3), 167-176.

52. Wang, Z., Xie, N., \& Jin, Y. (2019). Do loan loss provisions affect the credit fluctuations in China's banking system? Emerging Markets 
Finance and Trade, 55(11), 2425-2436.

53. Weber, O. (2012). Environmental credit risk management in banks and financial service institutions. Business Strategy and the Environment, 21(4), 248-263.

Appendix: Matrix of correlations

\begin{tabular}{|l|l|l|l|l|l|l|}
\hline Variables & ROAE & NPL & LLR & ED & FD & TGE \\
\hline ROAE & 1.000 & & & & & \\
\hline NPL & -0.238 & 1.000 & & & & \\
\hline LLR & -0.194 & 0.611 & 1.000 & & & \\
\hline FD & -0.033 & -0.039 & 0.037 & 1.000 & & \\
\hline ED & 0.020 & 0.085 & -0.008 & -0.057 & 1.000 & \\
\hline TGE & -0.105 & 0.135 & 0.104 & -0.093 & 0.180 & 1.000 \\
\hline
\end{tabular}

\begin{tabular}{|l|l|l|l|l|l|l|}
\hline Variables & ROAA & NPL & LLR & ED & FD & TGE \\
\hline ROAA & 1.000 & & & & & \\
\hline NPL & 0.125 & 1.000 & & & & \\
\hline LLR & 0.085 & 0.105 & 1.000 & & & \\
\hline FD & 0.092 & 0.400 & -0.060 & 1.000 & & \\
\hline ED & 0.119 & 0.337 & 0.071 & 0.043 & 1.000 & \\
\hline TGE & 1.000 & 0.125 & 0.085 & 0.092 & 0.119 & 1.000 \\
\hline
\end{tabular}

\begin{tabular}{|l|l|l|l|l|l|l|}
\hline Variables & ROAA & NPL & LLR & ED & FD & TGE \\
\hline ROAA & 1.000 & & & & & \\
\hline NPL & 0.125 & 1.000 & & & & \\
\hline LLR & 0.085 & 0.105 & 1.000 & & & \\
\hline FD & 0.092 & 0.400 & -0.060 & 1.000 & & \\
\hline ED & 0.119 & 0.337 & 0.071 & 0.043 & 1.000 & \\
\hline TGE & 1.000 & 0.125 & 0.085 & 0.092 & 0.119 & 1.000 \\
\hline
\end{tabular}

AppendixB: Components plus residuals (ROAE Vs NPLs and ROAA Vs LLR)
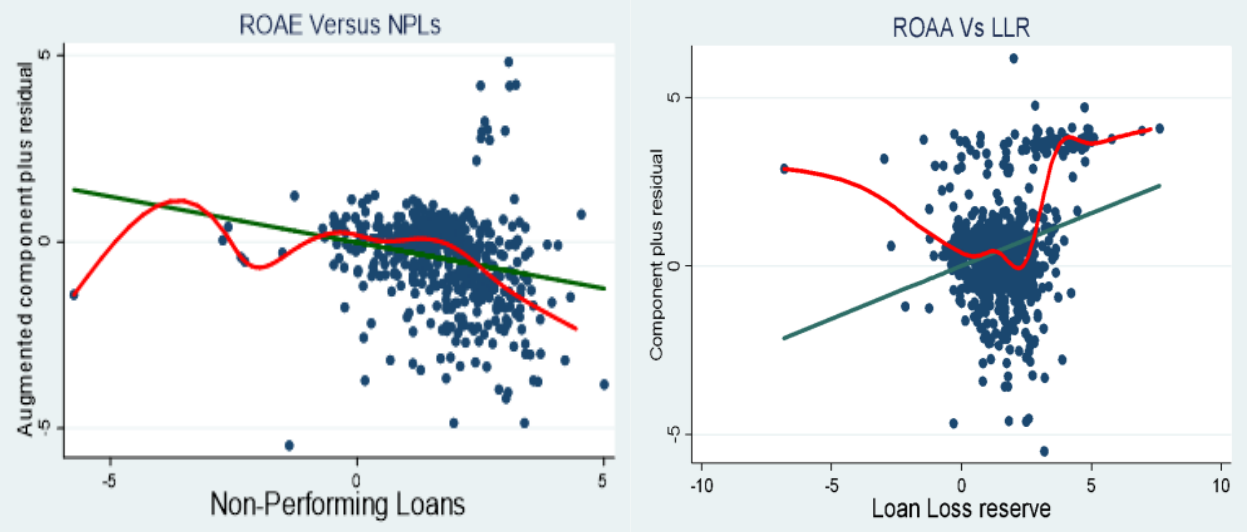